\title{
23. Artificial Meteor Ablation Studies
}

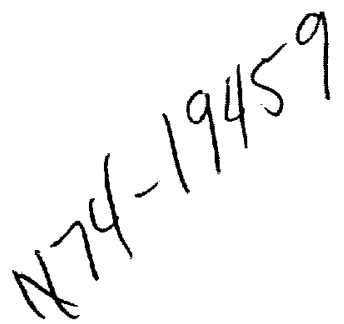

Maxwfll B. Blanchard Ames Research Cenier, NASA Moffett Field, California

Artificial meteor ablation was performed on natural minerals, composed predominately of magnetite and hematite, using an arc-heated plasma stream of air. Analysis of the ablated debris indicates most was composed of two or more minerals. Wustite, a metastable mineral, was found to occur as a common product. The "magnetite" model, whose content was 80 percent magnetite, 14 percent hematite, 4 percent apatite, and 2 percent quartz, yielded ablated products consisting of over 12 different minerals. Magnetite occurred in 91 percent of all specimens examined, hematite in 16 percent, and wustite in 89 percent. The "hematite" model, whose content was 96 percent hematite and 3 percent quartz, yielded ablated products consisting of over 13 different minerals. Hematite occurred in 47 percent of all specimens examined, magnetite in 60 percent, and wustite in 28 percent. The more volatile elements (Si, $P$, and $\mathrm{Cl}$ ) vere depleted by a reduction of about 50 percent in the amounts present. Also, the relative abundance of $F$ increased as a result of both volatile depletion (loss of $\mathrm{Si}, \mathrm{P}, \mathrm{Cl}$, and $\mathrm{Ca}$ ) and a reduction in its oxidation state. Hematite was converted to magnetite in the ablation zone along the model's front face. Also, quartz and apatite minerals were converted to an $F e$-rich glass consisting of varying amounts of $\mathrm{Si}, \mathrm{P}, \mathrm{Cl}$, and $\mathrm{Ca}$, depending upon the accessory minerals available at the time of melting. These glass phases occurred as unusual myrmekiticlike intergrowths, which are unique textural indicators of the environment through which the material has survived. The chemistry and mineralogy of these phases remains the only trace of the original minerals. This study has shown that artificially created ablation products from iron oxides exhibit unique properties that can be used for their identification. These properties depend on the composition of the original material and the environmental conditions of formation. In addition to the accepted elemental criteria, these properties are morphologic characteristics, textural parameters, and the existence of metastable minerals.

$\mathrm{O}$ VER THE PAST FEW YEARS many investigators have searched for cosmic dust. They have examined particles from sediments (Marvin and Finaudi, 1967), glacial ice (Hodge et al., 1967), and the atmosphere. Atmospheric particles have been collected using aircraft (Carr, 1970), balloons (Brownlee and Hodge, 1969), and rockets (Farlow et al., 1970). In some instances, particle collections have been so sparse that long and involved analytical methods have had to be used to demonstrate even the existence of any specimens (Ferry et al., 1970, and Blanchard et al., 1968). In other instances, the abundance of particles has been overwhelming (Hemenway and Soberman, 1962). In either case, however, the basic problem was to identify the cosmic dust particles and scparate them from the artificial and naturally occurring terrestrial contaminants. 
Investigators have had only limited success at making positive identifications. Elemental cvidence has been the main requisite to substantiate cosmic origin. The mast common approach has been to examine the collection for a group of particles containing Ni. Usually occurrenec of $\mathrm{Ni}$ in sufficient quantity to correlate with $\mathrm{Ni}-\mathrm{Fe}$ meteorites, or more simply cosmic abundance, allows a case for cosmic origin to be made. Of course, possible contaminants must be ruled out first. Indeed, certain investigations (Blanchard and Farlow, 1966; Blanchard et al., 1967) have shown this latter need quite effectively. However, the relative abundance of Ni-rich particles has been small when compared with the total population. For example, less than 3 percent of spherules collected from Greenland ice contained Ni (Hodge et al., 1967). The remaining particle types are often characterized by a similar assemblage of elements but without Ni. More recently, the occurrence of Ti has been proposed to indicate a volcanic origin for Fe-rich spherules (El Gorcsy, 1967). Early investigations suggested the occurrence of $\mathrm{Mn}$ to indicate a terrestrial origin, but recent studies (El Goresy, 1967) indicate Mn has no genetic importance. At any rate, firmer criteria for identifying particles of cosmic origin are necded.

The most recent results obtained by the Smithsonian's short-lived phenomena program (Anonymous, 1970), indicate large quantities of cosmic material are reaching Farth. Results of the Prairic Network (McCrosky, 1968) have shown a frequency of fireballs perhaps two orders of magnitude greater than earlier studies. Even though large amounts of cosmic dust are reaching the Earth's surface, very little is being positively identified because $\mathrm{Ni}$ abundance is not an adequate criterion. More emphasis on chemistry and mincralogy is required for firm cosmic identification.

Meteors, fircballs, and micrometeoroids have one property in common: they ablate while entering the Earth's atmosphere. Nicrometeoroid interaction with the atmosphere has been examined theoretically (Kornblum, 1969) and results indicate only submicron-size particles may pass through the atmosphere unaltered. Morcover, those particles in the micron size range would be nearly, if not entirely, ablated away. Iarger bodiss experience vaporization and fragmentation during entry. That destructive action on these larger bodies may be severe has been shown by experiments designed to study drag, ablation, and radiation effects using a constricted-arc supersonic jet to simulate metcor entry to the Earth's atmosphere (Shepard et al., 1967).

Using this unique experimental facility, it has been possible to simulate meteor ablation under controlled conditions. Initial studies (Blanchard, 1969) showed that mineral fractionation played a key role in determining the form and type of products formed. These products showed a resemblance to the parent body (Blanchard, 1970a and b) but also exhibited features characteristic of this unique environment.

Therefore, a new series of experimental studies in artificial meteor ablation has been initiated for the purpose of learning more about the reactions and products resulting from the ablation environment. This paper is the first of several that will present results of artificial ablation experiments performed on synthetic and natural materials designed to determine those features occurring in naturally ablated products characteristic (or nearly so) of the ablation environment.

\section{PROCEDURE}

The models used for these experiments were "magnetite" and "hematite," each with accessory minerals. The facility used for these artificial meteor ablation experiments was a constricted-are supcrsonic jet (fig. 1). Operation of the arc jet requires a potential difference of about $1 \mathrm{kV}$ bctween the tungsten cathode and multiple anode; a current of about $100 \mathrm{~A}$ is used. A plasma is gencrated that flows from the cathode toward the anode, consisting of: electrons, a small amount of argon used to bathe the cathode to reduce its oxidation rate, and high-pressure air ionized to simulate the Earth's atmosphere through which the artificial meteor is traveling. By matching the chamber pressure and the nozzle exit pressure the plasma stream is focused into a near-parallel shaped beam. Faeility conditions established for these experiments simulate a low velocity meteor traveling about $12 \mathrm{~km} / \mathrm{s}$ at an altitude of $70 \mathrm{~km}$.

A pan-shaped copper collector, with a watercooled jacket to prevent melting, was precleaned and placed inside the chamber. The model to be 


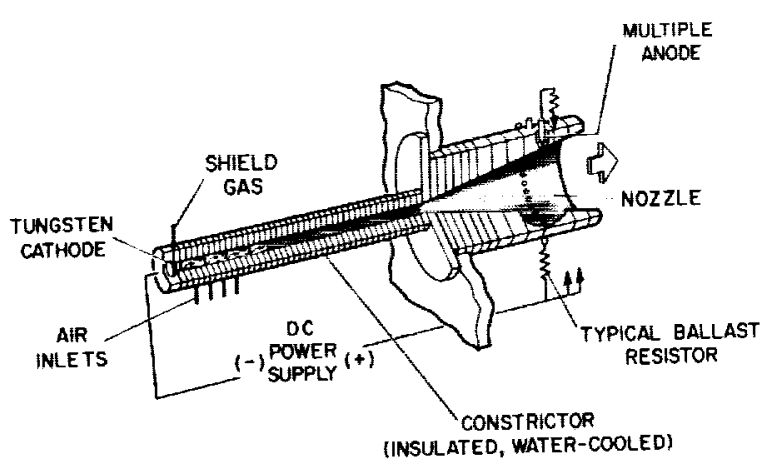

Figure 1.-Schematic drawing of a constricted-arc supersonic jet.

ablated was mounted facing the arc jet on a hollow rod cooled by water circulating within it. The model was moved by a servomechanism into the plasma beam after the beam was focused. The entire pcriod of ablation usually lasted no more than $30 \mathrm{~s}$. Generally, about 90 percent of the ablated material was recovered on the collector and chamber floor. The remaining material, distributed throughout the tunnel, was too contaminated for analytical use.

Material recovered from the chamber floor was sorted from any obvious contaminants. Despite attempts to minimize contamination by precleaning the chamber with a vacuum cleaner and repeated washings with distilled water and absorbent papcr towels, small chips from screws, bolts, and other sources were occasionally found. However, all material on the collector was contaminant free. This latter material was immediately recovered after the experiment and returned to a cleanroom where the debris was removed from the collector using a brush and a strong pressure rinse with trifluorotrichlorocthane. The material was flushed into filtering apparatus and finally recovered on a membrane filter. This procedure prevented contamination in the particle size range below $1 \mathrm{~mm}$.

Optical microscopy studies were performed using the stereo microseope by subdividing the material into groups based on particle morphology. Each group was weighed and counted. Representative numbers of particles from each group were selected for analysis. Analyses were performed using a metallurgical microscope, x-ray diffraction/fluorescence and an electron microprobe. For all analyses, the original model, the ablated front face, and the debris collected were compared. Metallurgical microscopy studies consisted of viewing polished specimens with brightand dark-ficld incident light to examine textures and identify phases. Only a few samples of each particle group were examined in this manner. X-ray fluorescence studies consisted of determining relative abundance of the principal elemental constituents in the models for making comparisons with the collected debris. Bulk samples were examined to detect changes in abundance of volatile elements.

The principal analytical method for identifying the many iron oxide phases was $\mathrm{x}$-ray diffraction which easily and reliably separates all of the iron oxide minerals. Over 1000 individual particles ranging from $10 \mu$ to $700 \mu$ were analyzed. Specimons were mounted on this glass rods and positioned inside 57.3-mm-diameter Debyc-Scherrer cameras. Exposure periods ranged from 12 to 24 hr using Ilford-G film. All camcras were purged with helium gas during the exposure period to minimize background from air scatter. Identifications were made using film overlays similar to that shown in figure 2. Data for all suspected minerals were taken from ASTM cards and converted into Debye-Scherrer film format on a stable base drafting medium. Phototransparencies were then made with six separate patterns on each transparent overlay. Most of the particles contained two or more minerals; these particles were identified by visually subtracting the diffraction pattern for each major constituent in the film, leaving the most intense lines from minerals remaining to be matched again.

Electron microprobe studies using the MAC Model 400 were performed on the original model and on the ablation zone along the model's front face. Over 100 individual grains of each mineral present in the model were qualitatively analyzed with an energy dispersive, silicon detector and a multichannel pulse height analyzer. Grains in the model and those in the ablated zone along the frontal face wore then compared for elemental homogeneity.

Quantitative analyses were performed with spectrometers having cither a sealed proportional detector using a IiF crystal, or a flow proportional detector using an ADP or PET crystal depending on the wavelength and peak-to-background ratio 


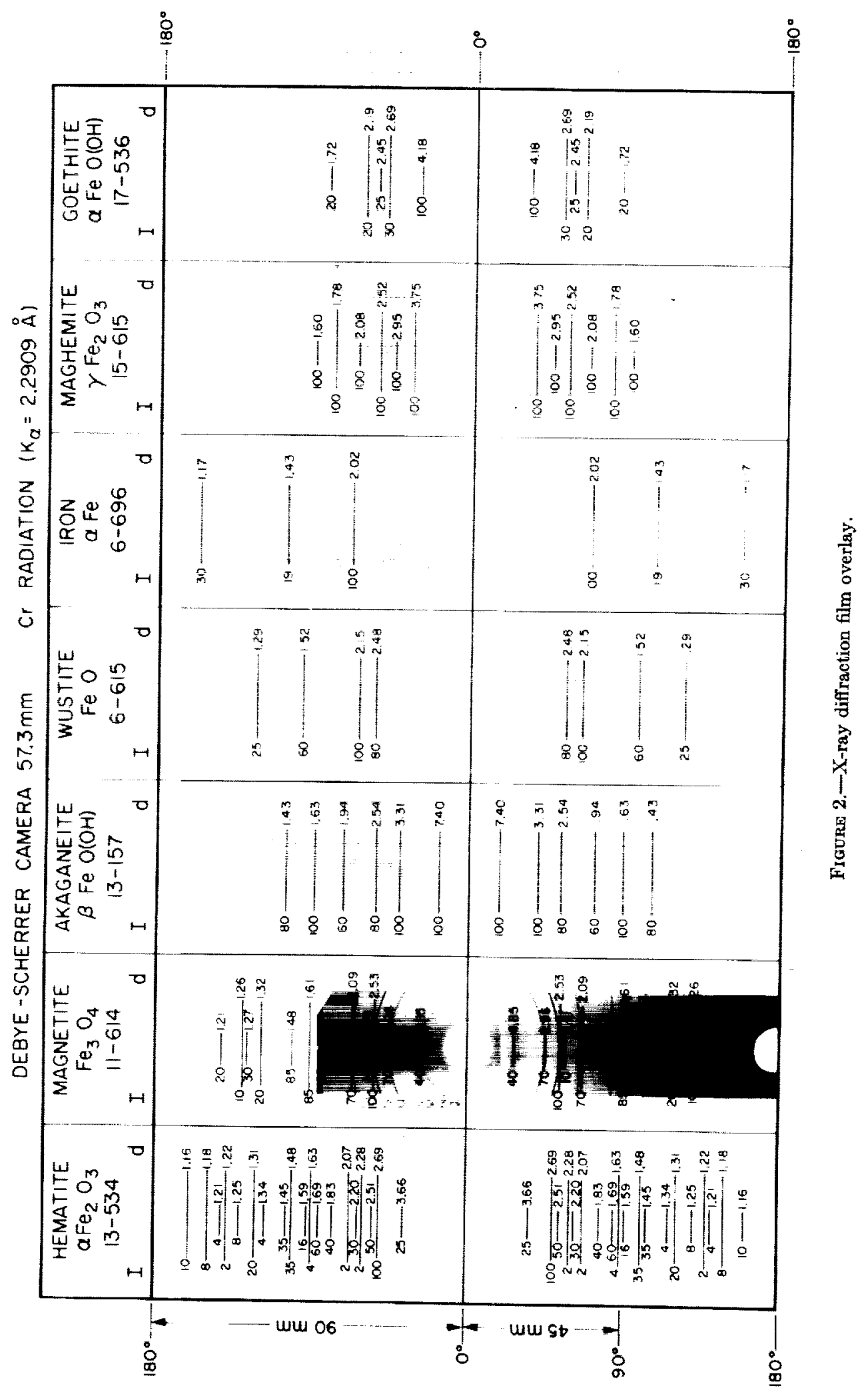


required. All analyses were conducted with an accelerating potential of $25 \mathrm{kV}$. Specimen current for qualitative analysis using the energy-dispersive detector was usually $0.0100 \mu \mathrm{A}$. For quantitative analysis using the crystal spectrometers it ranged between 0.0050 and $0.0100 \mu \mathrm{A}$, depending on the nature of the grain to be analyzed. Corrections for drift, background, and detector dead time wore applied to all data. Absorption corrections werc made using the method outlined by Adler and Goldstein (1965). Heinrich's (1966) mass absorption values were used in this procedure. X-ray fluorescence corrections were made using Colby's (1966) procedure. Atomic number corrections were made according to Thomas's (1964) procedure.

\section{RESULTS AND DISCUSSION}

\section{Optical Studies}

Particles found on the collector were subdivided into groups on the basis of their morphology. Figure 3 illustrates the particle groups; their descriptions are given in table 1 . Groups $C$ and $D$ represent those particles not readily exhibiting characteristies of melted products and substantiate that at least a certain part of the ablated debris does not look like melted products. For these experiments, this portion of the debris represented 20 percent by weight of all collected products. A histogram of the collected debris from the "magnetite" ablation experiment showing its weight percent and the quantity of particles in each group is shown in figure 4. The distribution of particle groups and their relative amounts compares favorably for both "hematite" and "magnetite" models even though the amount of "hematite" ablated was less than 10 percent of the amount of "magnetite" ablated. A frequency size distribution was made for the group $\mathrm{X}$ particles (fig. 5). This positively skewed distribution indicates the bulk of the small particle debris centers about a median value of $354 \mu$. However, there is a sizable quantity of debris generated by the ablation process in the size range down to 2 or $3 \mu$. Smaller particles probably exist but are not collected because they remain in the plasma beam and are evenly dispersed throughout the chamber. A quantity of particles in the 1 to $100 \mu$ size range were recovered on membrane filters and showed a great diversity of colors, e.g., ycllow, red, orange, clear, milky. Because many of these also appear in particle collections taken with the plasma beam operating but without a model ablating, most are probably contaminants from the facility. However, many molten particles as small as a few microns in size struck larger bodies already solidified on the collector leaving splatter marks on the surface of the larger bodies (fig. 6).

\section{X-Ray Diffraction Studies}

X-ray diffraction analysis of approximately 1000 individual ablated specimens was performed. Particle sizes ranged from 10 to $700 \mu$. Selected specimens from each morphologic group were $\mathrm{ex}-$ amined in numbers proportional to the amount present in each group. Those selected were judged to be most typical for that group, although an unusual specimen was almost always examincd. Because most of the specimens analyzed contained two or more minerals the diffraction patterns were complex. Development of the film overlay technique, using actual ASTM file data converting $d$ values into measurements drawn on transparent films, allowed rapid identifications for most of the diffraction patterns. Table 2 shows the magnetite data compiled from 614 patterns, of which 59 percent contained two or more minerals. The "magnetite" mineral model was composed of 80 pereent magnetite, 14 percent hematite, 4 percent apatite, and 2 perent quartz. The hematite occurred interstitially between cuhedral magnetite grains. Over 12 different minerals were recognized in the ablation products. Note that the frequency of occurrence given cannot be compared with percent abundance. Magnctite, for example, will be somewhat less in abundance than the 91 percent frequency of occurrence suggests because it occurred alone, as a major constituent mixed with other minerals, and occasionally as a minor constituent. Hematite and wustite will be considerably less in abundanee than the 16 pereent and 39 percent listed because they occurred almost exclusively as minor constituents. Hematite occurred alone only occasionally and wustite only rarely. Nearly all the wustite identified was based on the four most intense $d$ spacings; only two patterns had five (all that can be recorded on film using $\mathrm{Cr}$ radiation) of the eight lines listed on the ASTM card. All of 


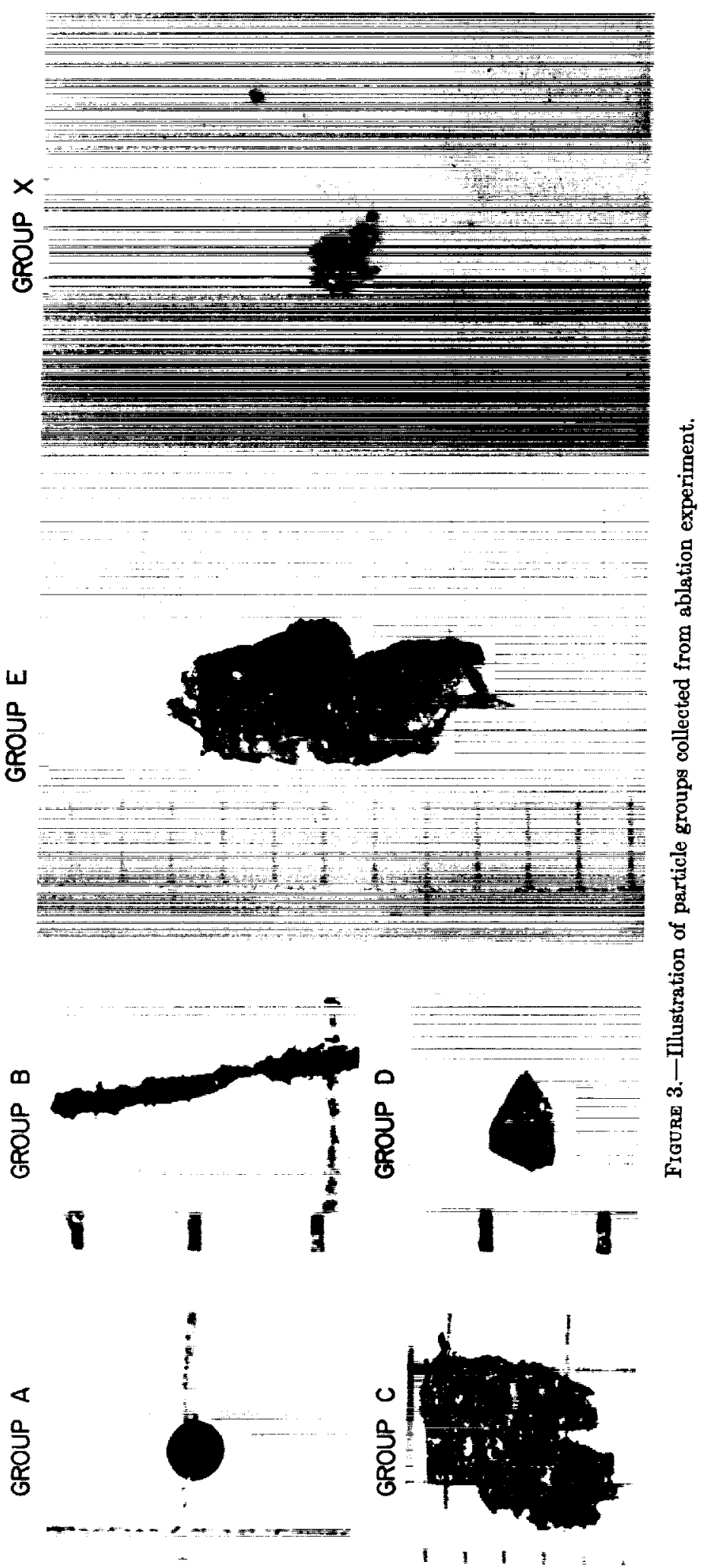


TABLE 1-Characteristics of Particle Groups Collected From Ablation Experiment

\begin{tabular}{|c|c|c|c|}
\hline Group & Shape & Color & Texture \\
\hline A & $\begin{array}{l}\text { Spheres, spheroids, flattened sphe- } \\
\text { roids; many have protuberances. }\end{array}$ & $\begin{array}{l}\text { Fresh-silver } \\
\text { Oxidized-red brown, brown, } \\
\text { copper, gold, blue, purple, gray, } \\
\text { black }\end{array}$ & $\begin{array}{l}\text { Dull lusterless finish on red brown and } \\
\text { gray particles; metallic colors have } \\
\text { shiny surface but are not often } \\
\text { smooth; general surface appears } \\
\text { grainy, some are rough and scaley; } \\
\text { many show voids; some are hollow. }\end{array}$ \\
\hline B & $\begin{array}{l}\text { Flattened droplets and elongated } \\
\text { pieces; length-to-width-ratio } \\
>5 \text {. }\end{array}$ & $\begin{array}{l}\text { Fresh-silver } \\
\text { Oxidized-red brown, brown, } \\
\text { copper, blue, gold, gray, black }\end{array}$ & $\begin{array}{l}\text { Dull lusterless finish on red brown and } \\
\text { gray particles; metallic colors have } \\
\text { shiny surface but are not often } \\
\text { smooth; surface appears grainy; } \\
\text { some particles are very rough and } \\
\text { show discrete octahedrons; many } \\
\text { voids at surface. }\end{array}$ \\
\hline $\mathrm{C}$ & $\begin{array}{l}\text { Platelike, very thin flat chips } \\
\text { generally equant or rectangular } \\
\text { outlines. }\end{array}$ & $\begin{array}{l}\text { Fresh-silver } \\
\text { Oxidized-red brown, brown, } \\
\quad \text { copper, blue, gray, black }\end{array}$ & $\begin{array}{l}\text { Dull lusterless on red brown and gray } \\
\text { particles; metallic colors have a shiny } \\
\text { surface but are not smooth; some } \\
\text { show discrete octahedrons; many } \\
\text { have very small }(<10 \mu) \text { flattened } \\
\text { droplets on the top surface. }\end{array}$ \\
\hline $\mathrm{D}$ & $\begin{array}{l}\text { Pyramidal, tabular, equant blocks } \\
\text { and granules; no more than one } \\
\text { side shows melted surface; most } \\
\text { easily distinguished by angular } \\
\text { edges and broken sides; collec- } \\
\text { tor shaped surface and melted } \\
\text { surfaces are not readily } \\
\text { recognized. }\end{array}$ & $\begin{array}{l}\text { Almost all have fresh surfaces } \\
\text { that yield a shiny silver and } \\
\text { black color; only occasionally } \\
\text { are oxidized surfaces found. }\end{array}$ & $\begin{array}{l}\text { Characterized by freshly broken edges } \\
\text { and sides; all particles have angular } \\
\text { appearance; voids occur. }\end{array}$ \\
\hline $\mathrm{F}$ & $\begin{array}{l}\text { Irregular or ropy bodies; shape } \\
\text { controlled by collector; melted } \\
\text { surfaces immediately recog- } \\
\text { nized; length-to-width ratio }>2 \\
\text { or } 3 \text {; some have octahedral } \\
\text { crystals at surface. }\end{array}$ & $\begin{array}{l}\text { Fresh edges are shiny silver or } \\
\text { black, collector shaped sides } \\
\text { are shiny gray, sometimes blue } \\
\text { or gold; melted surface ranges in } \\
\text { color from dull red brown to } \\
\text { shiny gold, silver, or gray. }\end{array}$ & $\begin{array}{l}\text { Shapp pointed edges and grainy surface } \\
\text { features; voids are dominant; octa- } \\
\text { hedral crystals are common. }\end{array}$ \\
\hline $\mathbf{X}$ & $\begin{array}{l}\text { Pyramidal, tabular, granular, } \\
\text { platelike chips, flattened drop- } \\
\text { lets, and spherules; all particles } \\
\text { smaller than } 1 \mathrm{~mm} \text {. }\end{array}$ & $\begin{array}{l}\text { Yellow, red, orange, elear, milky, } \\
\text { amber, gray, black, silver. }\end{array}$ & $\begin{array}{l}\text { Ranges from freshly broken edges and } \\
\text { sides to shiny smooth surfaces. }\end{array}$ \\
\hline
\end{tabular}

the hematite identified had four or more of the most intense lines. Most of the time eight or more lines were present. Magnetite's identification was almost always based on the presence of 12 or more lines in the diff raction pattern. Patterns that were not identified usually could be divided into about five separate mineral groups based on pattern similarities.

An attempt was made to correlate mineral content of the particles with carlier recognized morphologic groups (fig. 3 and table 1). Results are shown in table 3 for the "magnetite" model.
Note that all groups (cven those not readily exhibiting signs of having been melted) reflect about the same frequency of occurrence for magnetite, hematite, and wustite. This characteristic suggests that mineralogical trends can be established from a smaller quantity of samples and even by restricting the specimens to one particle group. Irepidocrocite appears only in irregularshaped particles, whereas gocthite appears only in particles rescmbling thin platclike chips. Perhaps this association can be best explained by the uniqueness of the particle groups in that they both 


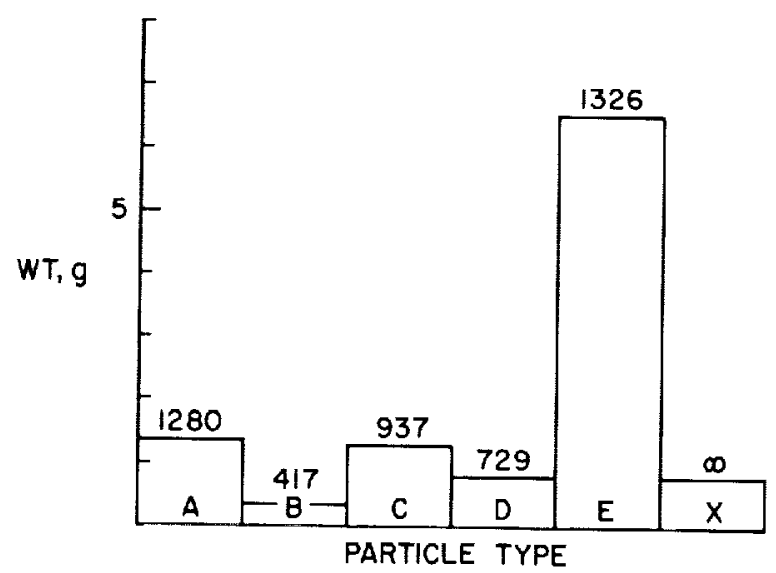

SAMPLE $X=$ ALL PARTICLES SMALLER THAN Imm

Figure 4.-Collected debris from magnetite model.

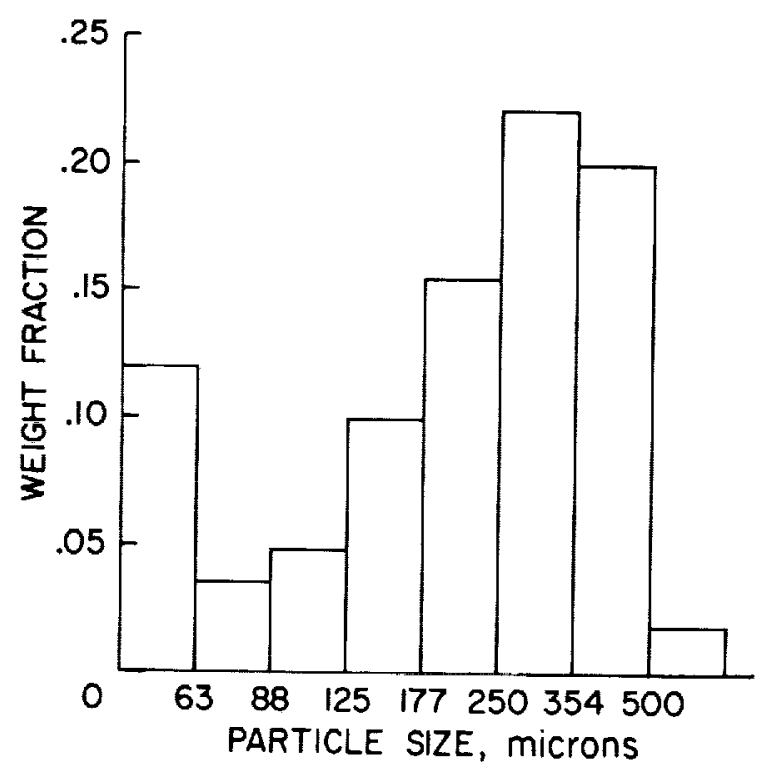

Figere 5.-Frequeney size distribution of group $X$ particles.

have an unusually high ratio of surface arca to volume, which favors the formation of alteration products.

With the foregoing results in mind, an examination of hematite ablation products was performed. However, a lower quantity of specimens was examined: 181 particles were analyzed, of which 56 pereent contained two or more minerals. Table 4 gives data from the hematite analysis. The model was composed of 96 percent hematite, 3 pereent quartz with some magnetite. Magnetite occurred

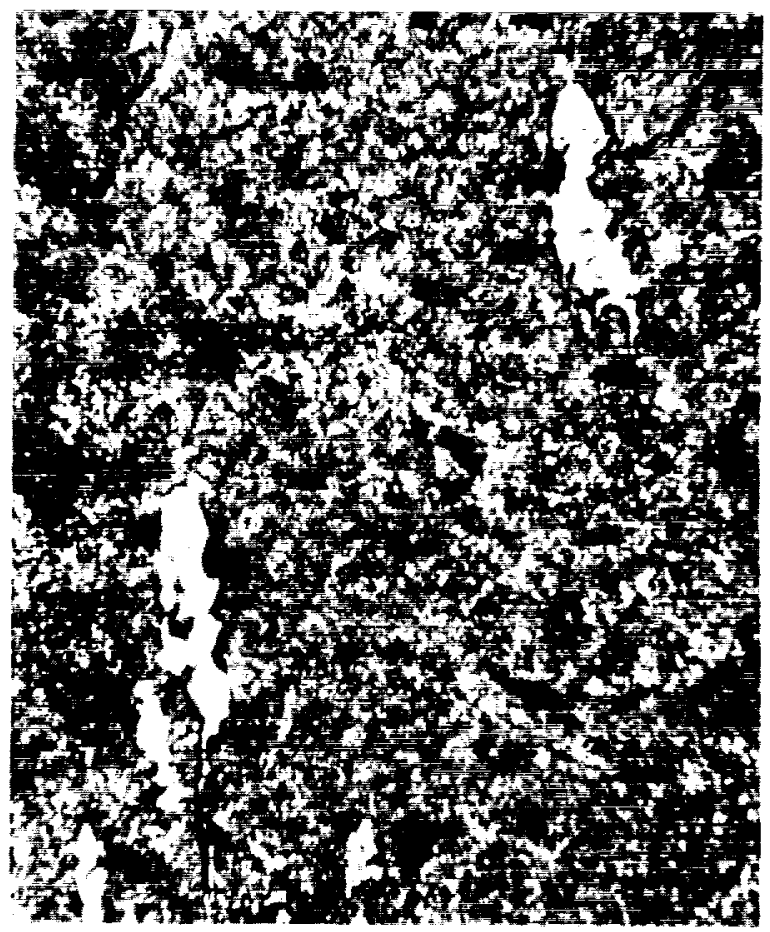

Figure 6.-Flattened droplet with micron size splatter drops.

as a few small individual octahedral crystals in a porous matrix of hematite. Over 13 different minerals were recognized in the ablation products. These minerals were identified in a manner similar to that for the "magnetite" model. The most significant difference noted was the reduction in the amount of hematite present and, at the same time, a dramatic increase in the amount of magnetite and wustite present in the products. As before, the existence of unidentified patterns suggest about five minerals may be represented. The occurrence of akagancite, lepidocrocite, and goethite are believed to be post ablation alteration products probably from magnetite. Copper particles encountered came from the collector or facility chamber parts. Aluminum particles originated from a pan used to cover the collector during transit.

\section{X-Ray Fluorescence}

Analyses were conducted on bulk powdered samples from the model and ablated products. These studies wcre performed to correlate the "bc- 
TARLe 2.-X-Ray Diffraction Analysis of Ablation Products From "Magnetite" Model

\begin{tabular}{|c|c|c|c|}
\hline \multirow{2}{*}{ Mineral } & \multicolumn{2}{|c|}{ Occurrence $^{\mathrm{a}}$} & \multirow{2}{*}{$\begin{array}{c}\text { Percent } \\
\text { frequency of } \\
\text { occurrence }\end{array}$} \\
\hline & $\begin{array}{c}\text { Major } \\
\text { constituent }\end{array}$ & $\begin{array}{c}\text { Minor } \\
\text { constituent }\end{array}$ & \\
\hline Magnetite & 549 & 12 & 91 \\
\hline Hematite & 5 & 94 & 16 \\
\hline Wustite & 2 & 236 & 39 \\
\hline Lepidocrocite & 2 & & $<1$ \\
\hline Goethite & 1 & & $<1$ \\
\hline $\begin{array}{l}\text { Unknown } \\
(=5 \text { different } \\
\text { patterns })\end{array}$ & 20 & 1 & 3 \\
\hline $\begin{array}{l}\text { Copper } \\
\text { contaminant }\end{array}$ & 15 & & 2 \\
\hline $\begin{array}{l}\text { Aluminum } \\
\text { contaminant }\end{array}$ & 2 & & $<1$ \\
\hline
\end{tabular}

Total number of particles analyzed: 614 $41 \%$ patterns with one mineral

$59 \%$ patterns with two or more minerals
TABLE 4.-X-Ray Diffraction Analysis of Ablation Products From "Hematite" Model

\begin{tabular}{l|c|c|c}
\hline \multirow{2}{*}{ Mineral } & \multicolumn{2}{|c|}{ Occurrence } & $\begin{array}{c}\text { Percent } \\
\text { frequency of } \\
\text { occurrence }\end{array}$ \\
\cline { 2 - 3 } & $\begin{array}{c}\text { Major } \\
\text { constitucnt }\end{array}$ & $\begin{array}{c}\text { Minor } \\
\text { constituent }\end{array}$ & \\
\hline Hematite & 67 & 18 & 47 \\
Magnetite & 84 & 25 & 60 \\
Wustite & 2 & 49 & 28 \\
Akagancite & 3 & 4 & 4 \\
Lepidocrocite & 1 & 1 & 1 \\
Goethite & 2 & 1 & 1 \\
Unknown \\
$\begin{array}{c}\text { ( }=5 \text { different } \\
\text { patterns) }\end{array}$ & 9 & 1 & 6 \\
Copper \\
contaminant & 3 & 4 & 4 \\
Aluminum \\
contaminant
\end{tabular}

a Total number of particles analyzed: 181 . $44 \%$ patterns with one mineral $56 \%$ patterns with two or more minerals

Table 3.-Comparison of Particle Shape With Mineral Conient of Ablated Products From "Magnetile" Model

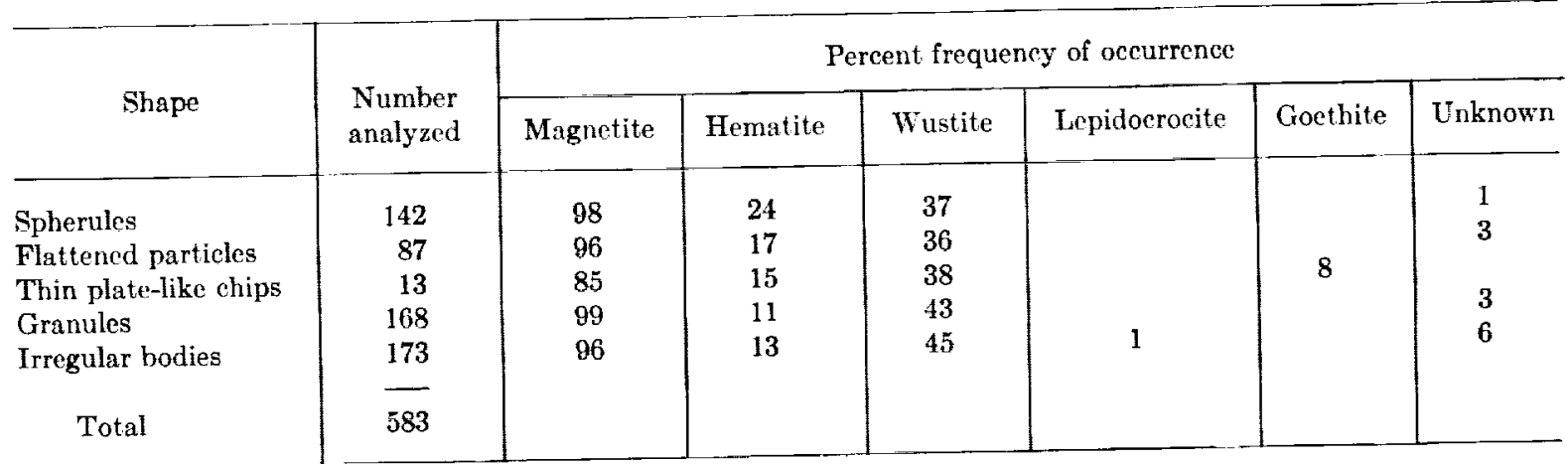

forc" and "after" chemistry. Farlier experiments (Walters and Giutronich, 1967) have demonstrated that vapor fractionation can seriously affect the end products by depleting certain morc volatile elements. The role of vapor fractionation in the formation of the ablation products was indicated by analysis of powdered samples of the model and products. As shown in table 5 the elements $\mathrm{Si}, \mathrm{P}$, and $\mathrm{Cl}$ show strong cvidence of volatile depletion by about 50 percent reduction in amounts present. The element $\mathrm{Ca}$ shows an apparent depletion of 20 percent of the amount present. An increase in the relative abundance of
$F c$ is a result of both volatile depletion and a reduction in its oxidation state. This last feature is discussed in more detail later.

\section{Electron Microprobe Analysis}

Flectron microprobe analyses were performed on the "magnetite" and "hematite" models and along the ablated portion on their front faces. Figure 7 is a photomicrograph of a polished surface for these models. In the "magnetite" model, magnetite occurs as euhedral grains with hematite occurring principally at grain boundaries. Sub- 
TABI.E 5.-X-Ray Fluorescence Analyses

\begin{tabular}{l|c|c|c|c|c}
\multicolumn{1}{c|}{ Sample } & \multicolumn{5}{c}{$\begin{array}{c}\text { Principal elemental constituents } \\
\text { (weight percent) }\end{array}$} \\
\cline { 2 - 6 } & $\mathrm{Si}$ & $\mathrm{P}$ & $\mathrm{Cl}$ & $\mathrm{Ca}$ & $\mathrm{Fe}$ \\
\hline Magnetite model "B" & $2.4 \pm 0.5$ & $1.1 \pm 0.2$ & $0.3 \pm 0.1$ & $1.6 \pm 0.3$ & $61.0 \pm 2.0$ \\
Magnetite ablated "B" & $1.2 \pm 0.1$ & $0.5 \pm 0.1$ & $0.1 \pm 0.1$ & $1.3 \pm 0.2$ & $77.5 \pm 1.0$ \\
Hematite model & $1.8 \pm 0.3$ & & & & $63.7 \pm 1.6$ \\
Hematite ablated & $1.6 \pm 0.1$ & & & & \\
\hline
\end{tabular}
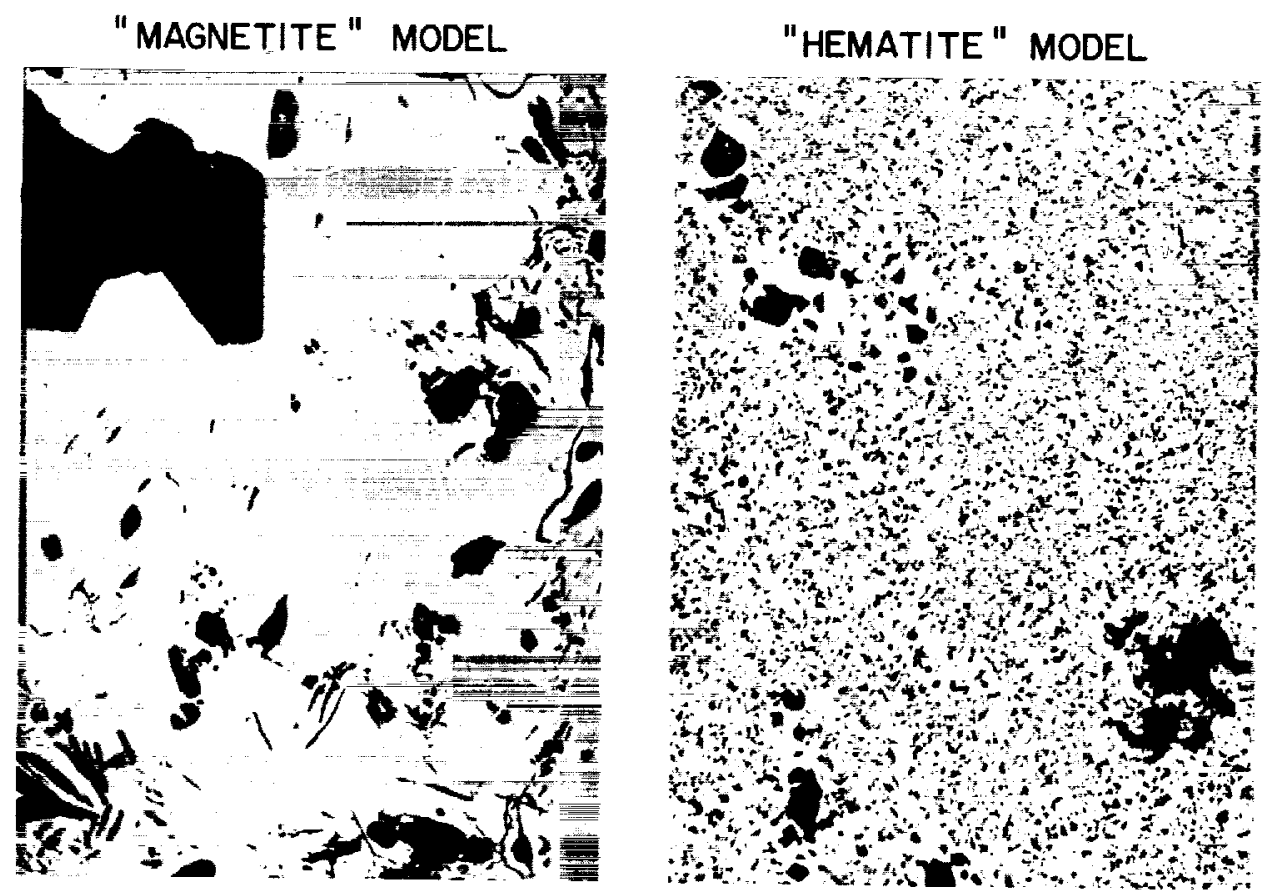

Figure 7,-Polished sections of "magnetite" and "hematite" models.

hedral grains of apatite and anhedral grains of quartz are encountered occasionally. For the "hematite" model, magnetite occurs as very few cuhedral grains isolated in a porous groundmass of mierocrystalline lematite. Oceasionally anhedral grains of quartz are cncountered. Table 6 reports results of the analysis for the principal elements in each mineral. For these analyses, over 10 different grains of each mineral were analyzed quantitatively for the elements listed. Many more grains were analyzed using an energy dispersive detector to ensure the homogencity of each mineral.

Analyses of the ablated zone on the front face of the "magnetite" model revealed several features; among them is the apparent conversion of all hematite to magnetite in this zone and in a melt zone extending a few hundred microns deep beneath this surface. New products here are the result of chemical reactions occurring in the gas cap on the front face of the model. These newly formed products from the "magnetite" model are illustrated in figure 8. In the upper left-hand corner the original minerals are secn; magnetite, hematite at the grain boundaries, and one rather large grain of apatite are evident. In the central portion of the figure the hematite has been converted to magnetite, which is the only conspicuous difference. Obviously, this zone reached a molten 
Table 6.-Electron Microprobe Analysis of Mineral Grains in Hematite and Magnetite Models and Their Ablated Products

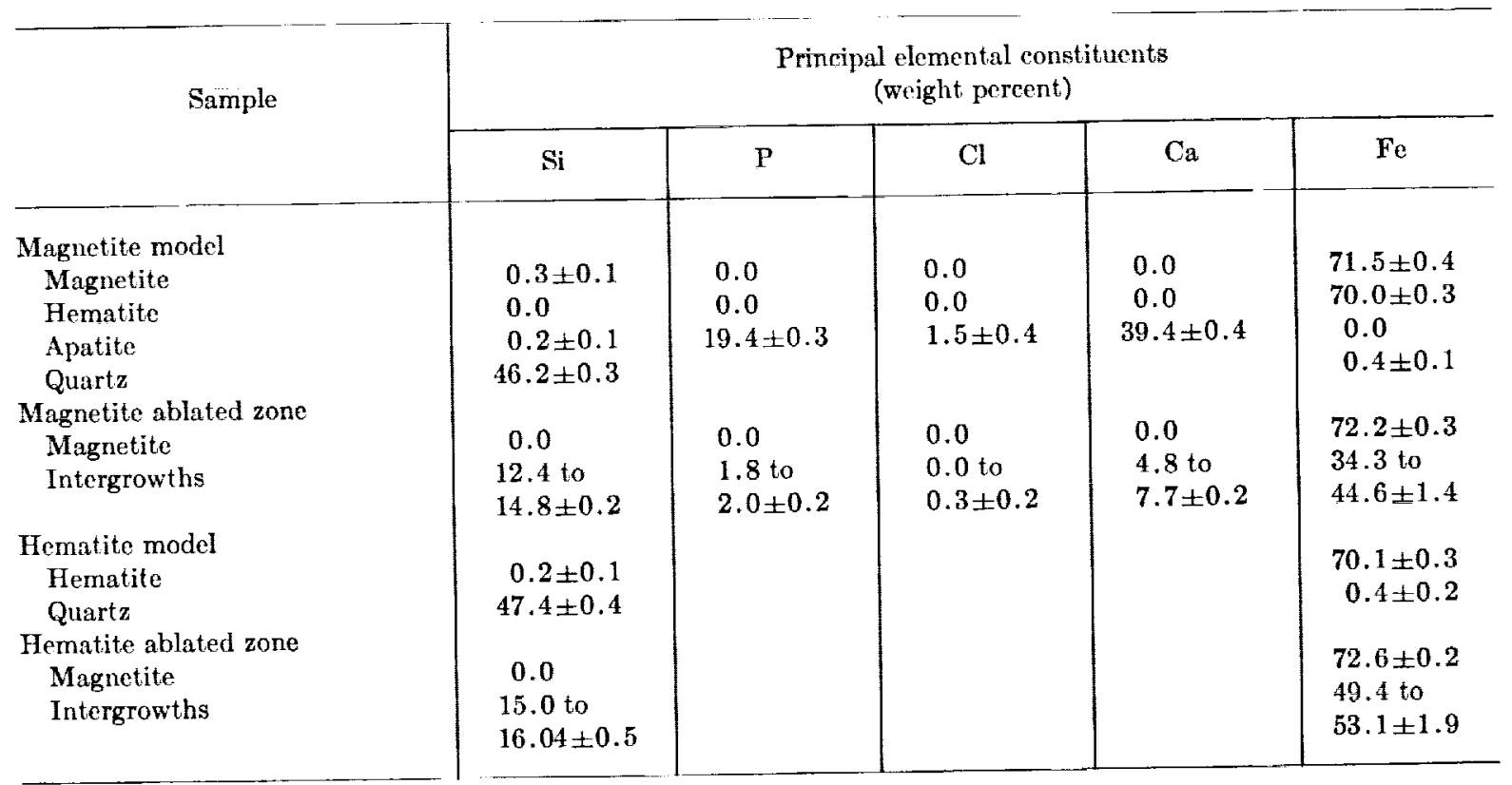

state and in a reducing environment which explains the absence of hematite. In the right-hand portion magnetite occurs with unusual myrmekitielike intergrowths, which exhibit planar features running generally parallel to the original orientation of the model's front face. Often the intergrowths themselves are aligned parallel with one another but perpendicular to the planar features. Electron probe studies have shown these intergrowths consist of the same elements but in different proportions. More quantitative studies showed the composition range to be 12.4 to 14.8 percent $\mathrm{Si}, 1.8$ to 2.0 pereent $\mathrm{P}, 0.0$ to 0.3 pereent $\mathrm{Cl}, 4.8$ to 7.7 percent $\mathrm{Ca}, 34.3$ to 44.6 percent $\mathrm{Fe}$, and 33.2 to 41.4 percent $O$. Oxygen content was detrirmined by subtracting the sum of all components from 100 pereent. The $\mathrm{Si}, \mathrm{P}, \mathrm{Cl}$, and $\mathrm{Ca}$ for this new phase came from quartz and apatite minerals occurring in the "magnetite" model. Iocal differences in the overall abundance of apatite and quartz from place-to-place within the model yiclded compositions which vary in abundance of $\mathrm{Si}, \mathrm{P}, \mathrm{Cl}$, and $\mathrm{Ca}$.

An illustration of newly formed products from the "hematite" model is shown in figure 9. In the upper left-hand side, the original mineral hematite is seen. In the central section, the hematite has been converted to magnetite. However, original surface textures are generally preserved from the hematite through this zone of magnetite. Obviously, this zone has reached a molten state and in a reducing environment, which explains the absence of any hematite. In the right-hand portion, magnetite again occurs with myrmekiticlike intergrowths similar to those of the "magnetite" model. However, electron probe studies revealed a different composition: 15.1 to 16.4 percent $\mathrm{Si}, 49.4$ to 53.1 percent $\mathrm{Fe}$, and 31.9 to 34.2 percent $\mathrm{O}$. This change in content results from the presence of quartz (and the lack of apatite) in the "homatite" model. Silicon for this phase came from the quartz.

X-ray diffraction Debye-Scherrer powder patterns were taken of several picces of this intergrowth material chipped from the edge of a polished specimen, and yiclded no pattern, suggesting the material was amorphous. This phase is considered to be an Fe-rich glass with varying amounts of $\mathrm{Si}, \mathrm{P}, \mathrm{Cl}$, and $\mathrm{Ca}$ depending on the availability of accessory minerals in the model at the time of melting. Clearly, these intergrowths are a unique textural indicator of the environment through which the matcrial has survived, and the chemistry and mineralogy of these phases remains the only trace of the original mincrals. 
ENTIRE MELT ZONE

MODEL A MOLTEN B ABLATED C

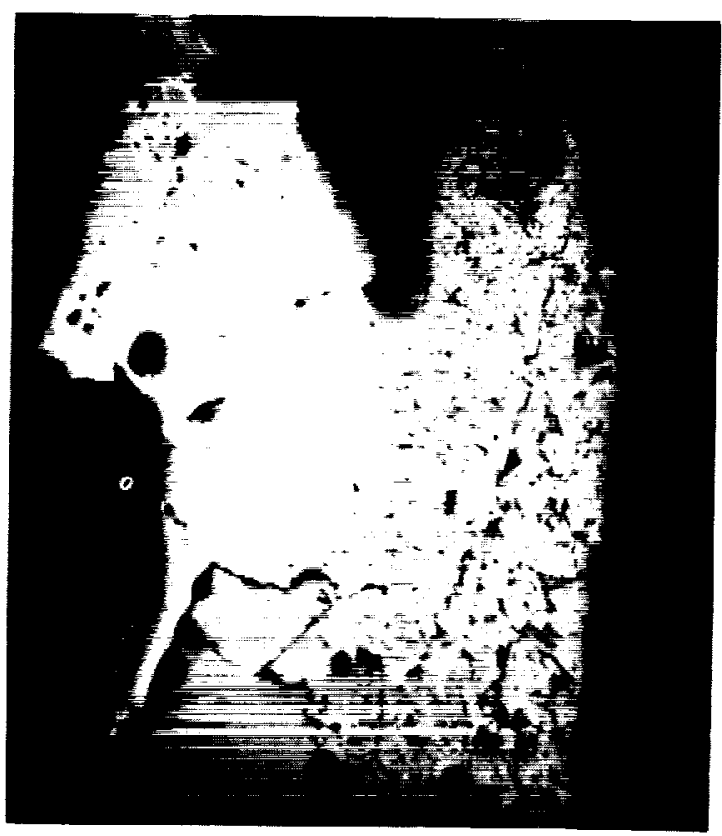

A-ORIGINAL MODEL, WITH MAGNETITE AND HEMATITE

B-MOLTEN ZONE, MAGNETITE ONLY, ORIGINAL TEXTURES PRESERVED

C-ABLATED ZONE, SHOWING MAGNETITE MYRMEKITIC-LIKE INTERGROWTHS COMPOSED OF Si, $\mathrm{P}, \mathrm{Cl}, \mathrm{Ca}, \mathrm{Fe}$ AND $\mathrm{O}$

Frgure 8.--Magnetite ablated model.

\section{CONCLUDING REMARKS}

This study has shown that artificially created ablation products from iron oxides exhibit unique properties that can be used for identification. These properties depend on the composition of the original material and the environmental conditions of formation. In addition to the accepted elemental eriteria, these properties are: morphologic characteristies, textural parameters, and the existence of metastable minerals.

Elemental criteria have been effectively used in
ENTIRE MELT ZONE

MODEL A MOLTEN B

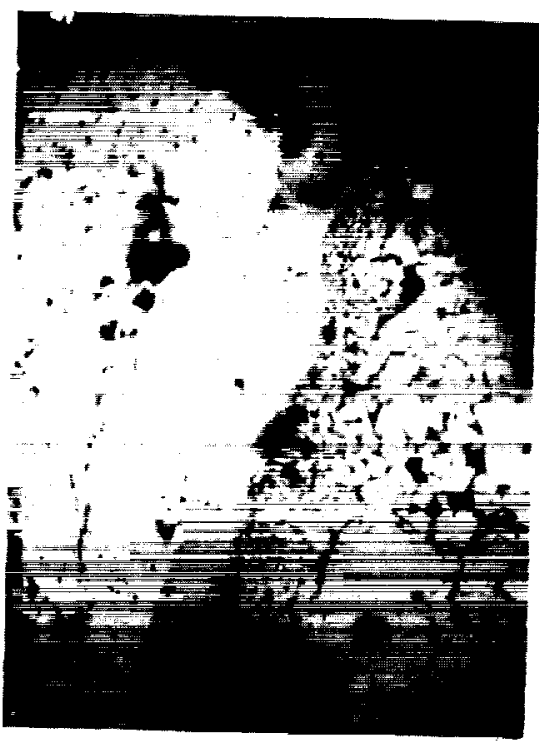

ABLATED $C$

A-ORIGINAL MODEL, WITH HEMATITE

B-MOLTEN ZONE, MAGNETITE ONLY, ORIGINAL TEXTURES PRESERVED

\section{C-ABLATED ZONE, SHOWING MAGNETITE PLUS MYRMEKITIC- LIKE INTERGROWTHS COMPOSED OF $\mathrm{Si}, \mathrm{Fe}$ AND $\mathrm{O}$}

Figure 9.-Hematite ablated model.

a recent investigation of debris collected by aircraft from the Revolstoke and Allende events (Carr, 1970). However, the largest particle size of this material was less than the minimum sizo examined in this study so application of the proposed properties will have to await further collections.

Morphological characteristics recognized in this study included spherules, flattened droplets, clongated particles, and irregular or ropy bodics with vesicular features. $A$ considerable portion of the debris found in this study was so fragile that many pieces less than $1000 \mu$ in size did not even appear as molted products, yet x-ray diffraction studies clearly showed that all were inderd melted products.

Textural parameters recognized in this study are the existence of myrmekiticlike intergrowths 
indicative of the ablation environment. Moreover, the clemental content of these glassy intergrowths offers the only real clues to the initial mincral content of the original body. Serious problems exist in extrapolating back to original mineral content using these phases because certain more volatile elements have been depleted.

Formation of a metastable mincral, wustite, occurred in this study. Wustite was only found in particles loss than $1000 \mu$ in sizc. Particles in this size range radiate heat sufficiently fast to produce a quenching condition, which is responsible for preserving the wustite.

The ablation facility simulated a metcor traveling approximately $12 \mathrm{~km} / \mathrm{s}$ at an altitude of 70 $\mathrm{km}$. At this altitude, the oxygen partial pressure is about $10^{-2} \mathrm{~mm}$. In contrast, the partial pressure of oxygen at sea level is about $160 \mathrm{~mm}$. Indications are the oxygen partial pressure may reach a maximum as high as $16 \mathrm{~mm}$ but only for a short time in the gas cap on the model's front face. While this environment oxidizes metallie iron, it reduces $\mathrm{Fe}_{2} \mathrm{O}_{3}$. Therefore, an upper limit is elcarly indicated for the oxygen nvailable to produce a reaction with the ablating material. Moreover, there is evidenen that molecular bound oxygen is lost from the hematite as revealed by mass spectrometry measurements (Ferry, 1970). This loss of oxygen together with rapid cooling explains the formation of wustite from both "magnetite" and "hematite" models. Loss of oxygen is also responsible for formation of magnetite from the "hematite" model. A temperature composition diagram for the iron-oxygen system (Darken and Gurry, 1946) shows that $\alpha$ iron and magnetitc would be the normal cxpected products if wustite was not prescrved by rapid cooling (fig. 10).

Formation of wustite during meteor ablation, and akaganeite, lepidocrocite, and goothite during later alteration, has been recognized for some time in metcorite fusion crusts. Wustite and akaganeite were also found in the fusion crust of the Sputnik IV fragment (Marvin, 1963). Sphrules of wustite have also been found associated with other material of suspected extraterrestrial origin (high nickel/iron ratio) from ancient (Marvin and

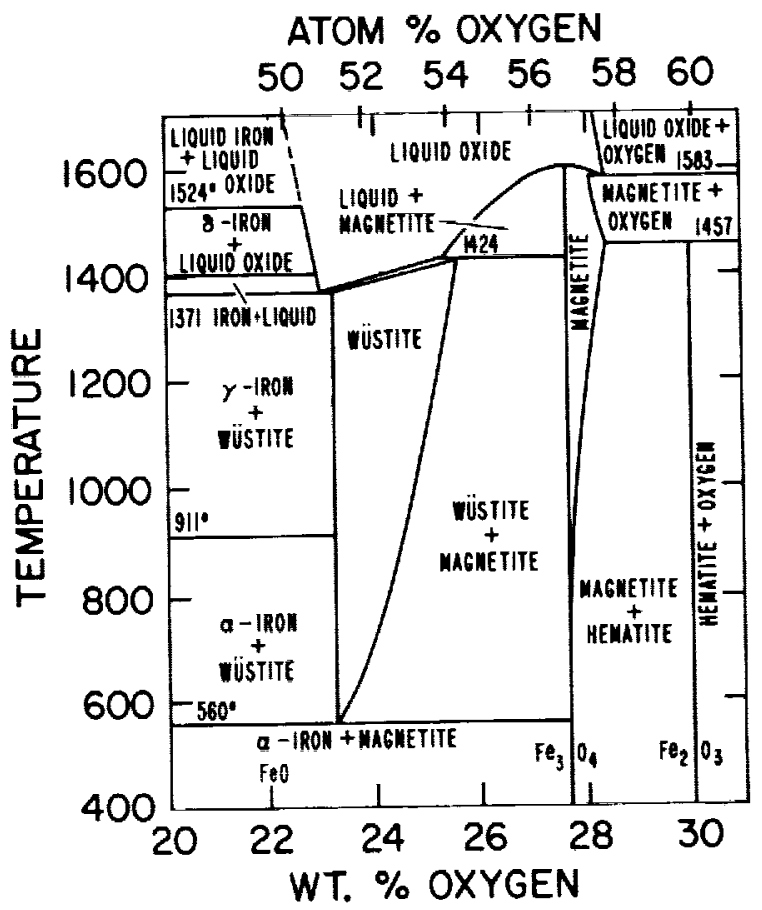

Figure 10.--Iron-oxygen system at a total oxygen pressure of one atmosphere; temperature-composition phase diagram. From Darken and Gurry, 1946. Ironoxygen equilibria involving liquid oxide, J. Amer. Chem. Soc., 68: 799 .

Einaudi, 1968) and marine (Millard and Finkelman, 1970) sediments. Assuming industrial contaminants have been ruled out, it appears the existence of wustite and its association with other iron oxides can be used as firm criteria in identifying debris ablated from metcors and fireballs.

\section{ACKNOWLEDGMENTS}

The author wishes to express his gratitude for assistance rendered by the following individuals: Richard Ferguson, clectron probe microanalysis; Gary Cunningham, x-ray fluorescence; Thomas Palmer, x-ray diffraction; and Franeis Hughes, microparticle manipulation. During the analysis, invaluable suggestions were rendered by H. D. Shade, G. V. Ferry, and N. II. Farlow. Sincerest appreciation is expressed to W. C. A. Carlson and C. E. Shepard of the Ames High Enthalpy Research Branch for their interest in the ablation project and their assistance in making the supersonic are jet facility available for these experiments. 


\section{REFERENCES}

Adler, I., AND Goldstein, J., 1965. Absorption tables for electron probe microanalysis, NASA Tech. Note D-2984, 267.

Anon., 1970. Annual report, 1969: Smithsonian Institution-center for short lived phenomena, Cambridge, Mass., 246 pp.

Blanchard, M. B., 1970a. Artificial meteor ablation studies of iron oxide minerals, EOS-Trans. Amer. Geophys. Union, 51, 831.

- 1970b. Wustite-a common occurrence in artificial meteor ablation products, Meleoritics, $\mathbf{5}$, 181 .

, 1969. Preliminary results of artificial metcor ablation (abstract), Meteoritics, 4, 261.

Blanchard, M. B., Ferry, G. V., and Farlow, N. H., 1968. Analyses of particles on surfaces exposed to the 1965 Leonid meteor shower by the Luster sounding rocket. J. Geophys. Res., $73,6347-6360$.

Blanchard, M. B., Farlow, N. H., Ferti, G. V., and Shade, H. D., 1967. Contaminants vi micrometeorites from the 1965 Leonid meteor shower, Proc. Amer. Assoc. Contam. Contr., $139-145$

Blanchard, M. B., and Farlow, N. H., 1966. Contamination control during designing, fabrication, test, and launch of an upper atmosphere rocket payload, J. Contam. Contr., 5, 22-25.

Browntee, D. F., ANd Hodge, P. W., 1969. Results of a large volume micrometeorite collection at an altitude of 115,000 feet (abstract), Meleoritics, 4, 264 .

CArr, M. H., 1970. Atmospheric collection of debris from the Revelstoke and Allende fireballs, Geochim. Cosmochim. Acta, 64, 689-700.

Colsr, J. W., 1966. The applicability of thenretically calculated intensity corrections in microprobe analysis, in The Electron Microprobe, edited by McKinley, Hcinrich, and Wittry, J. Wiley and Sons, 95-188.

Darken, L. S., and Gurry, R. W., 1946. The system iron-oxygen, II equilibrium and thermodynamies of liquid oxide and other phases, $J$, Amer. Chem. Soc., 68, 748-816.

Ex Gonesx, A., 1967. Flectron microprobe analysis and microscopic study of polished surfaces of magnetic spherules and grains collected from the Greenland Ice, Smithson. Astrophys. Obs., Spec. Rept. No. 251.

Farlow, N. H., Ferry, G. V., and Blanchard, M. B., 1970. Examination of surfaces exposed to a noctilucent cloud, Aug. 1, 1968, J. Geophys. Res., 75, 6736-6750.

Ferry, G. V., Blanchard, M. B., and Farlow, N. H., 1970. Microparticle collection experiments during the 1966 Orionid and Leonid meteor showers, J. Geophys. Res., 75, 859-870.

Ferry, G. V., 1970. Preliminary interpretation of mass spectra from artificial meteor ablation, Meteoritics, 5, 196-197.

Heinrich, K. F. J., 1966. X-ray absorption uncertainty, in The Electron Microprobe edited by MeKinely, Heinrich and Wittry, J. Wiley and Sons, 296-377.

Hemenway, C. I., and Soberman, R. K., 1962. Studies of micrometeorites obtained from a recoverable sounding rocket, Astron. $J$., 67, 256-266.

Hodge, P. W., Wright, F. W., and Langway, C. C., 1967. Studies of particles for extraterrestrial origin 5, compositions of the interiors of spherules from Aretic and Antaretic ice deposits, J. Geophys. Res., 72, 1404-1406.

Kornblem, J. J., 1969. Micrometcoroid interactions with the atmosphere, J. Geophys. Res., 74, 1893-1970.

Marrin, U. B., 1963. Mineralogy of the oxidation products of the Sputnik 4 fragment and of iron metcorites, J. Geophys. Res., 68, 5059-5068.

Marmin, U. B., and Einavd, M. T., 1967. Black, magnetic spherules from Pleistocene and recent heach sands, Geochim. Cosmochim. Acha, 31, 1871-1884.

McCrosky, R. F., 1968. The distribution of magnitudes, masses, and encrgies of large meteoritic bodies, Smithson. Astrophys. Obs. Spec. Rept. No. 280.

Millard, H. T., axd Finkflman, R, B., 1970. Chemical and mineralogical compositions of cosmic and terrest rial spherules from a marine sediment, J. Geophys. Res., 75, 2125-2135.

Siepand, C. F., Vormiter, J. W., Stine, H. A., ANd Wixovich, W., 1967. A study of artificial metcors as ablators, NASA Tech. Nole D-3740.

Thosas, P. M., 1964. A method for correcting for atomic number effects in electron-probe microanalysis, United Kingdom Atomic Energy Authority, Res. Group Rept. No. AERE-R4593.

Walters, L. S., Axd Gretronich, J. E., 1967. Vapor fractionation of silicate melts at high temperatures and atmospheric pressures, Solar Energy, XI, 163-169. 